CZASOPISMO INŻYNIERII LA¿OWEJ, ŚRODOWISKA I ARCHITEKTURY JOURNAL OF CIVIL ENGINEERING, ENVIRONMENT AND ARCHITECTURE JCEEA, t. XXXIV, z. 64 (3/II/17), lipiec-wrzesień 2017, s. 293-304, DOI:10.7862/rb.2017.173

\author{
Adam RYBKA ${ }^{1}$ \\ Rafał MAZUR
}

\title{
TERENY PRZYŁĄCZONE - STUDIUM PROBLEMU PROJEKTOWEGO NA PRZYKŁADZIE OSIEDLA PRZYBYSZÓWKA W RZESZOWIE
}

\begin{abstract}
W pierwszym dziesięcioleciu dwudziestego pierwszego wieku do Rzeszowa przyłączono obszar o powierzchni ponad sześćdziesięciu kilometrów kwadratowych. Tereny te stanowiły okoliczne wsie, które po włączeniu w granice miasta, nie zmieniły znacząco swojej struktury przestrzennej. Proces transformacji przestrzeni o rolniczym charakterze $\mathrm{w}$ przestrzeń miejską wymaga odpowiedniego przygotowania planistycznego. Reprezentatywnym obszarem, który pozwala na zdiagnozowanie kluczowych problemów jest Przybyszówka, której ostatnią część włączono do granic Rzeszowa w roku 2008. Zjawiska zaobserwowane na tym obszarze występują również na pozostałych terenach przyłączonych do miasta, które przy odpowiednim planowaniu mogłyby zostać zasiedlone przez ponad sto pięćdziesiąt tysięcy mieszkańców. Przed przystąpieniem do stworzenia głównych wytycznych planistycznych dla Przybyszówki, należy przeanalizować problemy już występujące oraz te, które mogą się pojawić w przyszłości. Znaczącym zagadnieniem wydaje się być identyfikacja problemów związanych z rozbudową istniejącej infrastruktury. Dotyczy to w głównej mierze komunikacji. Niemniej istotna jest problematyka rozwoju funkcjonalno-przestrzennego, który obecnie kształtuje się w oparciu o strukturę historyczną wiejskiej zabudowy oraz rozbudowę osiedli mieszkalnych w obrębie dawnej granicy miasta. Tereny przyłączone jako kontynuacja przestrzeni miejskiej powinny charakteryzować się zabudową o proporcjach i skali charakterystycznej dla Rzeszowa, która harmonizowałaby z zabudową już istniejącą. W artykule podjęte są zagadnienia, które mogą stać się punktem wyjścia do przyszłych decyzji planistycznych.
\end{abstract}

Słowa kluczowe: rozwój terytorialny Rzeszowa, przekształcenia urbanistyczne, skala i proporcje przestrzeni miejskiej, powiększanie granic miast

${ }^{1}$ Autor do korespondencji/corresponding author: Adam Rybka, Politechnika Rzeszowska, Zakład Urbanistyki i Architektury, ul. Powstańców Warszawy 12, 35-959 Rzeszów; tel.: 17865 1624; e-mail: akbyr@prz.edu.pl 


\section{Wprowadzenie}

\subsection{Problem badawczy}

W ciągu ostatnich kilkunastu lat powierzchnia Rzeszowa zwiększyła się ponad dwukrotnie. Przyłączanie do granic administracyjnych okolicznych miejscowości sprawiło, że miasto o wysokiej gęstości zabudowy stało się obecnie bardzo zróżnicowane pod względem intensywności zabudowy. Nowe tereny posiadają zazwyczaj typowo wiejski charakter, który w przyszłości ma ulec faktycznemu przekształceniu $\mathrm{w}$ typowo miejskie tereny. Proces ten niesie wiele zagrożeń dla jakości nowo powstającej przestrzeni (rys. 1.).

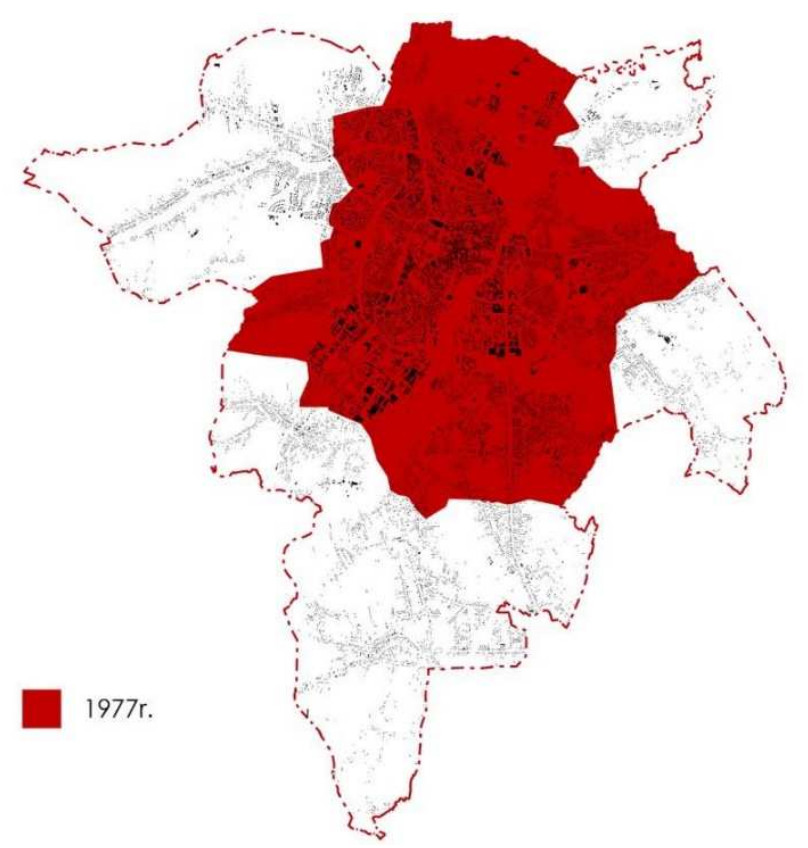

Rys. 1. Współczesne granice Rzeszowa w stosunku do granic z 1977 roku (autorzy: stud. inż. arch. Katarzyna Kulpa i Jadwiga Sobala)

Fig. 1. Contemporary boundaries of Rzeszow in relation to the 1977 borders (authors: students Katarzyna Kulpa and Jadwiga Sobala)

Podstawowym problemem planistycznym jest stworzenie nowej tkanki miejskiej, nawiązującej do charakteru całego miasta, sprzęgając ją jednocześnie $\mathrm{z}$ istniejącą zabudową. Na terenach przyłączonych do miast często występuje zjawisko, w którym nowe osiedla mieszkalne stykają się bezpośrednio z wiejską zabudową. Poza chaosem estetycznym, zjawisko to może powodować negatywne skutki pod względem społecznym. Integracja ludności miejscowej z ludno- 
ścią napływową powinna być obustronna. W wiejskiej lokalnej społeczności powinna pojawić się nowa tożsamość związana z całym miastem, przy jednoczesnym odczuciu lokalnej tożsamości nowych mieszkańców. Rozbudowa miasta bez odpowiedniego założenia planistycznego może również skutkować dużymi utrudnieniami w komunikacji. Rozwój terenów przyłączonych nie powinien się opierać na rozbudowie istniejących elementów infrastruktury, które były przewidziane do obsługi obszarów wiejskich. Nowe inwestycje powinny być realizowane według zupełnie odmiennych wytycznych.

Sprzężenie przyłączonych terenów z miastem jest obecnie jednym z najważniejszych zagadnień urbanistycznych dotyczących jego przyszłości. Pod koniec lat trzydziestych dwudziestego wieku władze Rzeszowa musiały zmierzyć się z perspektywą wielkiego rozwoju w związku z realizacją inwestycji Centralnego Okręgu Przemysłowego [6]. Przygotowany przez Dziewońskiego i Śmigielskiego plan rozbudowy miasta był jedną z przyczyn, dzięki którym po II Wojnie Światowej poszerzanie terytorium miasta przebiegało bez wielu negatywnych skutków. Dobra diagnoza problemów przyłączenia nowych terenów w dwudziestym pierwszym wieku może okazać się główną wskazówką do prawidłowego rozwoju.

Za reprezentacyjny przykład terenów przyłączonych może posłużyć teren dawnej wsi Przybyszówka, przyłączonej do Rzeszowa w trzech etapach. Pierwsze tereny włączono jeszcze w latach siedemdziesiątych. Jej zachodnią część, stanowiącą niegdyś centrum wsi, przyłączono w 2007 roku, a całość rok później. $\mathrm{Na}$ styku starej granicy Rzeszowa zaczęła powstawać zabudowa mieszkalna wielorodzinna, kontynuując istniejącą strukturę osiedla Krakowska Południe wybudowanego w latach osiemdziesiątych dwudziestego wieku. Struktura samej Przybyszówki jest systematycznie dogęszczana zabudową mieszkalną w sposób niekontrolowany, co sprawia, iż istniejąca infrastruktura staje się coraz bardziej niewydolna. Odpowiednie zdiagnozowanie problemów procesu rozwoju i wyznaczenie jego odpowiednich kierunku może pozwolić na zrównoważony rozwój Rzeszowa na nowych terenach przyłączonych.

\subsection{Stan badań}

Powiększanie się miast jest przewodnim tematem myśli urbanistycznej dziewiętnastego, dwudziestego i dwudziestego pierwszego wieku. Wykonano w tej kwestii wiele interdyscyplinarnych badań we wszystkich ośrodkach naukowych zajmujących się przestrzenią miejską. Wraz z szybkim rozwojem miast, powstało wiele idei, które zostały zrealizowane i zweryfikowane przez użytkowników oraz badaczy. Pomimo wielu prób odnalezienie najwłaściwszej drogi rozwoju dla miasta jest kwestią subiektywną i przede wszystkim indywidualną w odniesieniu do konkretnego miejsca.

Na tle współczesnych publikacji dotyczących struktury miasta wyróżnia się praca Dietmara Eberle przeprowadzona ze studentami ETH w Zurychu, w której 
zanalizowano trzydzieści sześć przestrzeni w obrębie czterech miast [3]. Wprowadzono kategorie intensywności konkretnych obszarów, które umożliwiły badaczom ich rzetelne porównanie. Poza powszechnie stosowanym wskaźnikiem intensywności zabudowy Eberle wprowadza wskaźnik intensywności atmosfery, który stanowi stosunek intensywności percepcji zmysłowej i konkretnego nastroju przestrzeni publicznych do powierzchni badanego obszaru. Intensywność atmosfery maleje wraz z intensywnością zabudowy, czego przykładem są rozlewające się przedmieścia, zdominowane przez przestrzeń prywatną. Zjawisko rozlewania się miast pojawiło się już sto lat temu w Stanach Zjednoczonych, a w Europie zaczęło być problemem w drugiej połowie dwudziestego wieku. W Polsce proces ten nasilił się w latach dziewięćdziesiątych. W Rzeszowie był on niewątpliwie inspiracją do powiększenia granic administracyjnych miasta na początku dwudziestego pierwszego wieku. Wśród wielu pozycji poświęconym powiększaniu się miast warto zwrócić uwagę na artykuł „Rola granicy we współczesnym mieście na przykładzie Warszawy” Marty Baranowskiej, w którym autorka w oryginalny sposób podjęła temat znaczenia granicy we współczesnym polskim mieście [1].Powiększanie granic Rzeszowa jest nieodłącznym elementem jego historii i zawsze miało duży wpływ na jego rozwój. Temat ten został skrupulatnie zbadany między innymi przez Władysława Heniga i Włodzimierza Bonusiaka [2]. Przyłączenia okolicznych miejscowości w pierwszym dziesięcioleciu dwudziestego pierwszego wieku, choć już analizowane przez urbanistów i badaczy z innych dziedzin, wciąż stanowią nowe pole do badań w kontekście przyszłości Rzeszowa.

\subsection{Metody badawcze}

Podstawową metodą badawczą omawianego zagadnienia jest obserwacja przemian społecznych i przestrzennych na terenie Przybyszówki. Procesy zachodzące od czasu przyłączenia miejscowości do Rzeszowa pozwalają na diagnozę problemów, które mogą pojawić się w przyszłości. Kolejnym krokiem jest określenie wytycznych projektowych, które będą logiczną odpowiedzią umożliwiającą zrównoważony rozwój terenów przyłączonych. Do tego celu posłużyć może analiza udanych rozwiązań urbanistycznych mogących znaleźć zastosowanie na omawianym obszarze. W ramach zajęć z przedmiotu „Przekształcenia struktur urbanistycznych" prowadzonych przez Zakład Urbanistyki i Architektury na Wydziale Budownictwa, Inżynierii Środowiska i Architektury Politechniki Rzeszowskiej, grupa studentów studiów magisterskich w pracowała nad koncepcją rozwoju Przybyszówki jako zintegrowanej części Rzeszowa. Projekt zakładał kilkukrotny wzrost liczby ludności na tym obszarze z 8940 do 50000 mieszkańców. Przebieg tych prac projektowych dostarczał interesujących spostrzeżeń oraz wniosków dotyczących potencjału nowych terenów przyłączonych, jak również zagrożeń, których uniknięcie wydaje się możliwe poprzez działania planistyczne przewidujące rozwój w najbliższych kilkudziesięciu latach. 
W związku z planowanymi przez władze miasta i regionu inwestycjami dotyczącymi budowy parku naukowo technologicznego lokalizowanego między innymi na północnym terenie Przybyszówki, opracowanie dotyczące rozwoju terenów mieszkalno-usługowych zawężono do obszaru na południe od alei Krakowskiej.

\section{Możliwości rozwoju terenów przyłączonych do Rzeszowa na przykładzie Przybyszówki}

\subsection{Charakterystyka miejsca}

Teren byłej wsi Przybyszówka jest atrakcyjny pod wieloma względami. Znajduje się $\mathrm{w}$ bezpośrednim sąsiedztwie zurbanizowanej przestrzeni osiedla Krakowska Południe. Dawny podział administracyjny nie stanowił pasa granicznego, który mógłby hamować rozwój nowej zabudowy. Na nowe inwestycje czeka powierzchnia dwunastu kilometrów kwadratowych przy znikomej gęstości zaludnienia. Przybyszówka obecnie ma charakter rolniczy. Warto zwrócić uwagę na jej walory estetyczne wynikające z ukształtowania terenu. Historyczna wieś rozwijała się w dolinie nad rzeką Przyrwą. Pola uprawne znajdują się na otaczających ją wzgórzach (rys. 2.).

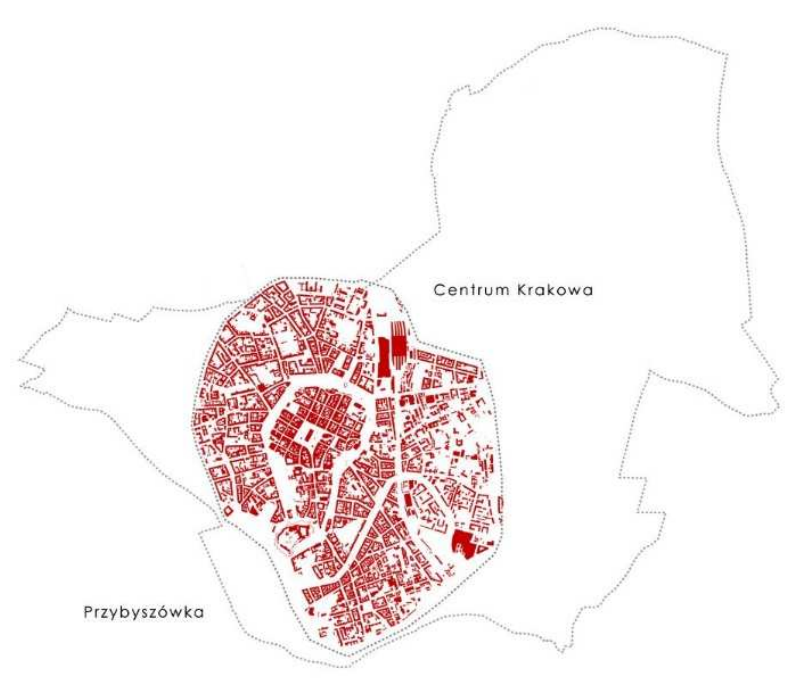

Rys. 2. Porównanie powierzchni Przybyszówki do centrum Krakowa (autorzy: stud. inż. arch. Katarzyna Kulpa i Jadwiga Sobala)

Fig. 2. Comparison of the area of Przybyszowka to the center of Krakow (authors: students Katarzyna Kulpa and Jadwiga Sobala) 
Nowa zabudowa od lat dziewięćdziesiątych rozwija się dwutorowo. Wzdłuż dawnej granicy z Rzeszowem, a szczególnie na terenach pierwszego przyłączenia, zrealizowano wiele inwestycji związanych z realizacją zespołów zabudowy jednorodzinnej oraz osiedla z zabudową wielorodzinną wykonywaną przez spółdzielnię mieszkaniową „Projektant”. Równolegle powstaje wiele drobnych inwestycji polegających na budowie domów jednorodzinnych w obrębie historycznej wsi wzdłuż ulic Dębickiej, Ustrzyckiej i Świdrówki. Budynki te realizowane są zazwyczaj w drugiej lub trzeciej linii zabudowy bez bezpośredniego dostępu do miejskich ulic. Dostęp do nich odbywa się często przez wąskie przesmyki służące niegdyś do obsługi gospodarstw rolnych. Drogi publiczne o parametrach odpowiadającym obsłudze terenów wiejskich przy coraz większym obciążeniu stają się coraz bardziej niewydolne. Przy takich uwarunkowaniach niemożliwa jest odpowiednia organizacja komunikacji publicznej.

Przestrzeń publiczna poza terenem szkół, domu kultury i kościoła parafialnego praktycznie nie istnieje. Choć Przybyszówka dysponuje dużym niezabudowanym i interesującym pod względem przyrodniczym terenem, w obrębie zurbanizowanym trudno jest o dostęp do zieleni i rekreacji. Duża powierzchnia obszaru dzielnicy i zabudowa skoncentrowana wzdłuż kilkukilometrowej ulicy Dębickiej są jedną z przyczyn uniemożliwiającym mieszkańcom korzystanie w sposób odpowiadający standardom przeciętnych miast. Dostęp do usług wydaje się praktycznie niemożliwy bez samochodu. Niewielka infrastruktura drogowa ograniczona jest tylko do obsługi ruchu kołowego. Przez Przybyszówkę przebiega trasa szybkiego ruchu S19, która jest obecnie w realizacji. Realizacja tej inwestycji nie poprawi znacząco warunków komunikacyjnych mieszkańców. Jej zasięg jest ponad lokalny, a lokalizacja trasy sprawia, że tereny Przybyszówki zostaną podzielone znaczącym pasem granicznym.

Uwarunkowania przestrzenne odzwierciedlają się w dwutorowym życiu społeczności. Jej rdzenna część wydaje się nie zmieniać swoich przyzwyczajeń poza przystosowywaniem się do coraz większych utrudnień komunikacyjnych. Społeczność napływowa, a szczególnie ta zamieszkująca budynki wielorodzinne zlokalizowane w obrębie dawnej granicy miasta, w żaden sposób nie jest zintegrowana z lokalną społecznością. Powstają dwa odrębne środowiska zarówno pod względem przestrzennym jak i społecznym. Nowi mieszkańcy domów jednorodzinnych na terenach dawnej wsi również nie mogą się integrować, ponieważ brak jest potrzebnej do tego celu przestrzeni publicznej, w której możliwe jest spotkanie z innymi mieszkańcami.

\subsection{Zagrożenia dotyczące przyszłego rozwoju przestrzennego}

Pogłębianie się procesów związanych z niekontrolowanym rozlewaniem się zabudowy w obrębie historycznej wsi oraz postępujący proces rozbudowy osiedli zabudowy wielorodzinnej od wschodu może spowodować nieodwracalne następstwa, które uniemożliwią zrównoważony rozwój całego obszaru Przyby- 
szówki. Istniejący układ komunikacyjny, ze względu na swoje parametry i ograniczenia w postaci otaczającej zabudowy, może stać się całkowicie niewydolny i niemożliwy do przebudowy. Zabudowa realizowana na podstawie warunków zabudowy i zagospodarowania terenu może w przyszłości zablokować konieczne inwestycje dotyczące niezbędnej infrastruktury. Istniejąca parcelacja terenu wynikająca z historycznego układu gospodarstw rolnych może sprawić, iż ich przekształcanie na tereny przeznaczone pod zabudowę mieszkalną zablokuje przyszłym mieszkańcom równomierny dostęp do usług i infrastruktury. W tym przypadku istotny jest również potencjał ekonomiczny rdzennych mieszkańców Przybyszówki, którzy są w posiadaniu terenów inwestycyjnych. Wartość działek niedostosowanych do potrzeb przyszłej zabudowy może być o wiele mniej opłacalny niż w przypadku przygotowanych działek pod zabudowę. Budowanie bez planu niesie ze sobą również zagrożenie powstawania obiektów o odmiennym charakterze estetycznym. Lokalizowanie zabudowy o różnych gabarytach bez przemyślanych wytycznych obejmujących rozwój całej Przybyszówki, może spowodować przestrzenny chaos, który w przyszłości będzie trudny do planistycznego uporządkowania.

Warto również zwrócić uwagę, iż bez wyprzedzającej interwencji władz miasta, potencjał terenów zielonych, które mogłyby obsługiwać również mieszkańców innych dzielnic, może zostać na zawsze utracony. Zielony ciąg wzdłuż rzeki Przyrwy i atrakcyjnie ukształtowany niezabudowany teren odpowiednio skomunikowane $\mathrm{z}$ innymi dzielnicami Rzeszowa mogłyby przyczynić się do polepszenia warunków życia mieszkańców jak również na wartość nieruchomości w ich obrębie.

Najbardziej dotkliwe wydają się zagrożenia związane z życiem społecznym w obrębie Przybyszówki. Pogłębiający się proces alienacji dwóch odmiennych społeczności, wynikający z budowy osiedli deweloperskich odizolowanych od lokalnej społeczności, w naturalny sposób staje się źródłem konfliktów. Niekontrolowana zabudowa o charakterze podmiejskim bez dostępu do przestrzeni publicznej tworzy pole do alienacji mieszkańców i zerwanie jakichkolwiek więzów społecznych.

\subsection{Możliwości projektowe}

Zagadnieniem kluczowym wydaje się wprowadzenie odpowiedniego układu komunikacyjnego, który umożliwiłby równomierne wykorzystanie powierzchni terenu. Zasadniczym aspektem projektowania powinien być system powiązania z pozostałą częścią miasta jak i złagodzenie obecnego problemu, dotyczącego przeciążenia ulicy Dębickiej. Jej ograniczone parametry z uwagi na otaczającą istniejącą zabudowę nie mogą zostać zmienione. Należy więc wykorzystywać zastany układ komunikacyjny jako drogi dojazdowe. Aby osiągnąć ten efekt, nowe drogi o lokalne i zbiorcze o niedużych parametrach powinny być usytuowane prostopadle do istniejącego historycznego układu. Ich zadaniem ma być 
połączenie obszaru z układem drogowym całego Rzeszowa; tj. z ulicą Krakowską od północy, ulicą Błogosławionej Karoliny od wschodu i z Kielanówką od południa.

Badania z ostatnich kilkudziesięciu lat dowodzą, iż gęsty układ dróg lokalnych może zaowocować lepszym funkcjonowaniem układu niż wprowadzanie do obsługi nowego terenu dróg o wysokich parametrach. W wielu miastach Europy Zachodniej oraz w Stanach Zjednoczonych likwiduje się w miastach drogi szybkiego ruchu, które często niszczyły funkcjonowanie dzielnic, a problemy komunikacyjne nie ustępowały. Najbardziej znanym przykładem jest przedsięwzięcie Roberta Mosesa w Nowym Jorku, które pociągnęło za sobą wiele negatywnych skutków, opisywanych przez Jane Jacobs już w latach sześćdziesiątych dwudziestego wieku [5]. Również w Rzeszowie można zauważyć, iż założenia drogowe $\mathrm{z}$ lat siedemdziesiątych i osiemdziesiątych nie rozwiązują problemów komunikacyjnych miasta. Gęsty układ dróg lokalnych może zaowocować równomiernym rozproszeniem się ruchu przy jednoczesnym powiązaniu ulicy z miastem. Ulica jako podstawowy element kompozycji urbanistycznej stanowi o jakości przestrzeni publicznej. Podążając za sprawdzonymi już w wielu miastach interwencjami Jana Gehla, ruch samochodowy nie może być na nich faworyzowany. Należy umożliwić sprawną komunikację publiczną jak również rowerową, co nie wyklucza sprawnego ruchu samochodów.

Na pierwszym miejscu powinien znajdować się pieszy jako główny użytkownik miasta. Ulice lokalne i zbiorcze powinny więc być otoczone usługami w parterach. Taka lokalizacja pozwala na odpowiednie ich rozproszenie na całym obszarze dzielnicy. W przeciwieństwie do sklepów wielkopowierzchniowych, usługi w parterach są łatwiej dostępne i dostosowane do percepcji człowieka [4]. Tworzą one również platformę do spotkania. W ciągu ostatnich dwudziestu kilku lat zwyczaje i sposób spędzania wolnego czasu uległy zasadniczej zmianie. Mieszkańcy miast coraz częściej korzystają z usług restauracji, a spędzanie wolnego czasu w kawiarniach staje się coraz ważniejszym elementem codziennej kultury. Polacy coraz częściej spędzają czas w miejskiej przestrzeni publicznej, co wpisuje się w ogólnoświatową tendencję. Jan Gehl zwraca uwagę, iż śródziemnomorski styl życia w mieście przenosi się również do krajów takich jak Islandia czy Norwegia, gdzie uwarunkowania przyrodnicze są o wiele mniej sprzyjające [4]. Atrakcyjność rzeszowskiej starówki pełnej kawiarnianych ogródków jest tego najlepszym dowodem.

Istotnym zagadnieniem jest skala zabudowy przyszłej Przybyszówki. Powinna ona wynikać z charakteru przestrzeni znajdującej się na obrzeżach miasta, jak również ze skali zabudowy typowej dla Rzeszowa. Nowa dzielnica nie powinna być obcym tworem, lecz przypominać o charakterze miasta, którego jest częścią. Ulice z usługami w parterach, które stanowiłyby trzon układu urbanistycznego, powinny nawiązywać swoją skalą do analogicznych przykładów w centrum miasta. Takimi referencyjnymi przestrzeniami wydają się być dwie 
rzeszowskie ulice, które z jednej strony stanowią przestrzeń o miejskim charakterze, $\mathrm{z}$ drugiej zaś odpowiadają uwarunkowaniom terenów peryferyjnych. Pierwszą jest ulica Szopena, której zabudowa wznosi się średnio do trzech kondygnacji, przy czym jej kąt środkowy oscyluje wokół 45 stopni. Szerokość pasa drogowego zapewnia wystarczające parametry. Podobnym przykładem jest ulica Księdza Józefa Jałowego, w której głównie dwu i trzykondygnacyjna zabudowa z pierwszej połowy dwudziestego wieku dopełniona wysoką zielenią nadaje przestrzeni wyjątkowego charakteru miasta. Ulice nowej dzielnicy Rzeszowa wzbogacone o infrastrukturę rowerową mogłyby się stać dobrą kontynuacją sprawdzonych rozwiązań. Niewielka skala zabudowy wielorodzinnej lokalizowanej wzdłuż głównych ulic nie wpływa na intensywność zabudowy, co potwierdzają badania Eberle. Liczne przykłady zrealizowanych przestrzeni miejskich o niewielkiej skali pokazują, iż jest ona bardziej przyjazna człowiekowi. Projektowana zabudowa wzdłuż głównych ulic Przybyszówki powinna mieć skalę trzech lub czterech kondygnacji z usługami w parterach (rys. 3.).

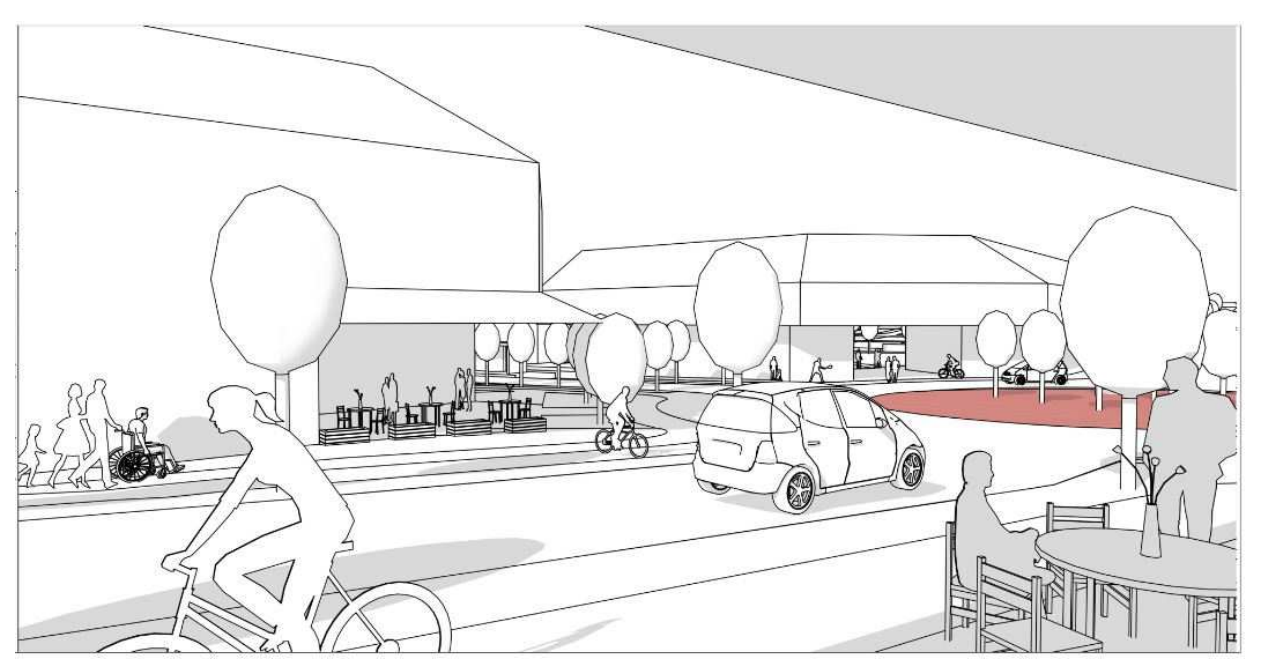

Rys. 3. Skala i proporcje nowych ulic. (autorka: stud. inż. arch. Katarzyna Posiewała)

Fig. 3. Scale and the proportions of the new streets.(author: student Katarzyna Posiewała)

Z uwagi na peryferyjną lokalizację nowej dzielnicy należy przewidzieć odpowiednią ilość miejsca na zabudowę jednorodzinną. Powierzchnia Przybyszówki zakładając taki rodzaj zabudowy jest w stanie pomieścić kilkadziesiąt tysięcy mieszkańców. Powinna być ona lokalizowana w obrębie kwartałów wyznaczonych przez lokalne ulice z zabudową wielorodzinną. Taki układ sprawia, iż mieszkańcy budynków jednorodzinnych będą mieli zapewniony łatwy dostęp do przestrzeni publicznej. Podobne układy dobrze funkcjonują już od dziewiętnastego wieku. Dobrym przykładem jest typowa struktura zabudowy Londynu, 
gdzie mieszkańcy niewielkich domów szeregowych mają szybki dostęp do głównych ulic z usługami i komunikacją publiczną. Najlepiej funkcjonującym polskim przykładem wydaje się Saska Kępa w Warszawie, w której historyczna już zabudowa jednorodzinna i niewielka zabudowa wielorodzinna skoncentrowana jest wokół pełnej życia i dobrze skomunikowanej ulicy Francuskiej. Osiedla zabudowy jednorodzinnej pozbawione dostępu do przestrzeni publicznych $\mathrm{w}$ formie dobrze skomunikowanej ulicy $\mathrm{z}$ usługami $\mathrm{w}$ parterach, stają się przestrzenią generującą problemy komunikacyjne i społeczne, z którymi zmaga się większość współczesnych miast (rys. 4.).

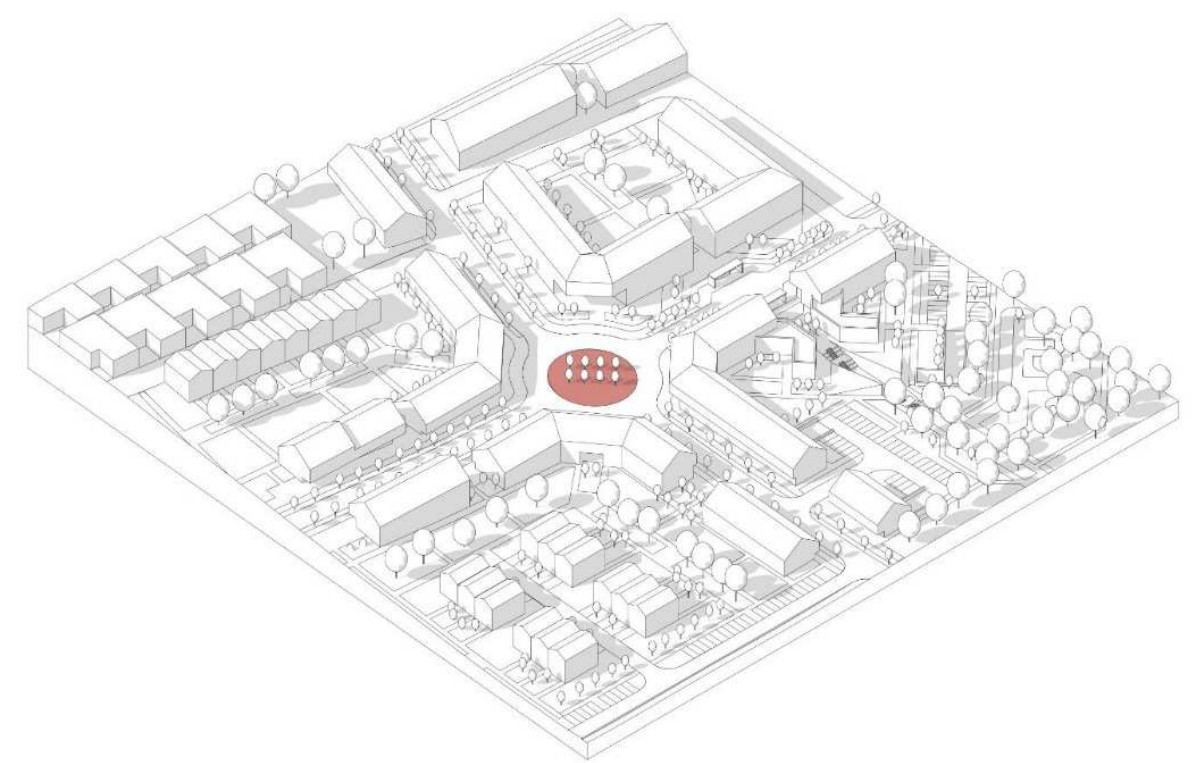

Rys. 4. Aksonometria fragmentu nowej tkanki miejskiej. (autorka: stud. inż. arch. Katarzyna Posiewała)

Fig. 4. Isometric view of the part of the new urban fabric.(author: student Katarzyna Posiewała)

\section{Podsumowanie}

Planując rozwój obszarów Przybyszówki, nie można zapomnieć o wiejskim charakterze przyłączonego terenu. Drewniana architektura budynków mieszkalnych lokalizowanych niegdyś wzdłuż dwóch głównych traktów komunikacyjnych po obu stronach rzeki powinna pozostać, a nowe inwestycje w jej rejonie powinny nawiązywać materiałem, skalą i charakterem do rdzennej zabudowy. Budynki o większej skali, lokalizowane wzdłuż nowych dróg, usytuowanych prostopadle do pierwotnego układu, stanowić będą nową formę, nawiązującą do charakteru Rzeszowa. W ten sposób możliwy jest rozwój zabudowy o miejskich parametrach, nie naruszając wiejskiej przestrzeni starej Przybyszówki. Jej loka- 
lizacja jest zarazem centralna w stosunku do całego obszaru dzielnicy, lecz równocześnie stanowi peryferyjny układ w obrębie nowych kwartałów zabudowy.

Nowa dzielnica realizowana $\mathrm{w}$ oparciu o prosty schemat komunikacyjny realizowany na pagórkowatym terenie może stać się bardzo interesującą przestrzenią pod względem estetycznym. Wykorzystanie w odpowiedni sposób uwarunkowań przyrodniczych może w przyszłości stanowić o charakterze tego miejsca. Intensywna zabudowa o niewielkiej skali z dostępem do usług i przestrzeni rekreacyjnej może sprawić, iż obrzeża Rzeszowa mogą być również atrakcyjnym miejscem do życia.

Problemy projektowe przedstawione na przykładzie Przybyszówki występują również na pozostałych terenach przyłączonych. Analogiczne rozwiązania planistyczne mogą być więc potraktowane w sposób uniwersalny. Dotyczyć to może zarówno przyłączonych terenów wiejskich do Rzeszowa, jak również przedmieść innych polskich miast, gdzie proces planowania przestrzennego nie był zsynchronizowany $\mathrm{z}$ gwałtownym rozwojem zabudowy po roku 1989 .

Tereny przyłączone do Rzeszowa w dwudziestym pierwszym wieku stanowią wielkie wyzwanie planistyczne. Problemy związane z niedrożną infrastrukturą, tożsamości mieszkańców i porządkiem przestrzennym mogą być w przyszłości rozwiązywane tylko na drodze planowania w szerszym kontekście całego miasta.

\section{Literatura}

[1] Baranowska M.: Rola granicy we współczesnym mieście na przykładzie Warszawy, Rzut, nr 11, 2016, s. 46-57.

[2] Dzieje Rzeszowa, tom I - IV, LibriResovienses, Rzeszów 1994-2012.

[3] Eberle D.: Density\&Atmosphere. On factors relating to Building Density in the European City, Birkhauser, Bazylea 2014.

[4] Gehl J.: Miasta dla ludzi, RAM, Kraków 2014

[5] Jacobs J.: Śmierć i życie wielkich miast Ameryki, Centrum Architektury, Warszawa 2014.

[6] Rybka A.: Centralny Okręg Przemysłowy a polska awangardowa urbanistyka międzywojenna, Oficyna Wydawnicza Politechniki Rzeszowskiej, Rzeszów 1995.

[7] Wejchert K.: Elementy Kompozycji Urbanistycznej, Arkady, Warszawa 2016.

\section{ADDED AREAS - STUDY ON EXAMPLE OF PRZYBYSZÓWKA DISTRICT IN RZESZÓW}

\section{S u m m a r y}

In the first decade of the twenty-first century Rzeszow was joined to an area of more than sixty square kilometers. These areas were the surrounding villages, which, when incorporated into the city limits, did not significantly change their spatial structure. The process of transforming 
agricultural space into urban space requires proper planning. A representative area that allows to diagnose key problems is Przybyszowka, whose last part was included in the boundaries of Rzeszow in 2008. The phenomena observed in this area are also present in other areas connected to the city, which, with proper planning, could be inhabited by over one hundred and fifty thousand inhabitants. Prior to setting up the main planning guidelines for Przybyszowka, one should analyze the problems already present and those that may occur in the future. It seems important to identify problems related to the expansion of existing infrastructure. This mainly concerns communication. Nevertheless, the issue of functional-spatial development, which is currently being built on the basis of the historical structure of rural development and the expansion of residential estates within the former city boundary, is significant. Areas connected as a continuation of urban space should be characterized by buildings with proportions and scale characteristic for Rzeszow, which would harmonize with already existing buildings. The article addresses issues that may be the starting point for future planning decisions.

Keywords: Territorial development of Rzeszow, urban transformations, scale and proportions of urban space, enlargement of city boundaries

Przestano do redakcji: 25.08.2017 r.

Przyjęto do druku: 01.09.2017 r. 